\title{
Bullying and submissive behavior ${ }^{*}$
}

\section{Gökhan ATIK ${ }^{* *}$ Onur ÖZMEN*** Gülşah KEMER ${ }^{* * * *}$}

\begin{abstract}
This study presents the prevalence and types of bullying and an examination of submissive behavior among Turkish high school students involved in bullying. Participants were 389 high school students $(59.6 \%$ males, $40.4 \%$ females) from three high schools in Ankara, Turkey. The Revised Olweus Bully/Victim Questionnaire (Olweus, 1996), Submissive Acts Scale (Gilbert \& Allan, 1994), and a brief demographic data sheet were used as measures. Bullying and its verbal and indirect forms were found to be prevalent among the adolescents. Regarding gender differences, male students were more involved in bullying than female students. According to the ANOVA results, victims reported more submissive behavior than bullies. The findings were discussed in the light of the literature, with some implications for school counselors and educators.
\end{abstract}

Keywords: Bullying, victimization, submissive behavior, high school students.

\footnotetext{
* This study were presented at the European Conference on Educational Research (2009, September), in Vienna, Austria. The authors thank Oya Yerin Güneri, Ph.D., for her invaluable feedbacks for this manuscript.

** Res. Assist,. Ankara University, Faculty of Educational Sciences, Guidance and Psychological Counseling, Ankara, Turkey. E-mail: gatik@ankara.edu.tr

*** Middle East Technical University, Faculty of Education, Guidance and Psychological Counseling, Ankara, Turkey. E-mail: onurozmen@msn.com

${ }^{* * * *}$ The University of North Carolina at Greensboro, School of Education, Department of Counseling and Educational Development, NC, USA. E-mail: g_kemer@uncg.edu
} 


\section{ÖZET}

Amaç ve Önem: Bu çalışmada, lise öğrencileri arasındaki zorbalık ve zorbalığa dahil olmuş öğrencilerin boyun eğicilik davranışlarının incelenmesi amaçlanmıştır. Elde edilen bulguların, lise öğrencileri arasındaki zorbalık olaylarının daha iyi anlaşılması ve bu tür olaylara dahil olan öğrencilerin sosyal davranışlarının ortaya konulması bakımından önemli katkılarının olacağı düşünülmektedir.

Yöntem: Çalışmaya Ankara'daki üç lisede eğitimlerine devam eden toplam 389 öğrenci katılmıştır. Bu öğrencilerin 232'sini (\%59.6) erkek, 157 $(\% 40.4)$ ise kız öğrenciler oluşturmaktadır. Katılımcılar uygun örnekleme yöntemi ile seçilmiştir. Katılımcıların yaşları 14 ile 19 arasında değişirken, yaş ortalaması yaklaşık olarak 16'dır. Zorbalığa ilişkin yaşantılar Revize Edilmiş Olweus Zorba/Mağdur Anketi (Olweus, 1996) ile değerlendirilmiştir. Boyun eğici davranışlar ise Gilbert ve Allan (1994) tarafindan geliştirilen Boyun Eğici Davranışlar Ölçeği ile ölçülmüştür. Bu ölçme araçlarının yanı sıra, katılımcıların cinsiyetleri, yaşları ve sınıf düzeyleri hakkında bilgi almak amacıyla bir kişisel bilgi formu hazırlanmıştır. Katılımcılar arasındaki zorbalığın yaygınlığını ve gerçekleşen zorbalık ve mağduriyet davranışlarının türlerini belirlemek için frekans analizleri yapılmıştır. Zorbalığa dahil olmanın cinsiyet ve sınıf düzeylerine göre farklılaşıp farklılaşmadığını incelemek için iki-yönlü çapraz tablo analizlerinden faydalanılmıştır. Son olarak; zorba, mağdur, zorba/mağdur ve dahil olmayan öğrencilerin cinsiyete göre boyun eğici davranışlarının farklılaşıp farklılaşmadığını araştırmak için de İki-Yönlü Varyans analizi kullanılmıştır.

Bulgular: Sonuçlara göre toplam 389 öğrencinin \%8'i zorba, \%19.8'i mağdur, \%7.7'si zorba/mağdur ve \%64.5'i dahil olmayan şeklinde dağılım göstermiştir. Zorbalık davranışının türü açısından, zorbaların kullandığı en yaygın zorbalık türünün ve kurbanların en çok maruz kaldıkları zorbalık davranışının sözel zorbalık ve dolaylı zorbalık ("gruptan ayrı tutma, dışlama, göz ardı etme" gibi) olduğu görülmüştür. Zorbalık davranışı ile ilgili olarak cinsiyet ve sınıf düzeyi değişkenleri incelendiğinde, anlamlı cinsiyet faklılıkları bulunmuştur. Ancak, sınıf düzeyi açısından anlamlı bir fark bulunmamıştır. Bu sonuca göre, erkek katılımcılar kızlara göre zorbalık olaylarına daha çok dahil olmuştur. Varyans analizi sonucuna göre de, mağdur kategorisinde yer alan öğrenciler ile zorba kategorisindeki öğrencilerin boyun eğici davranış puanları anlamlı bir şekilde farklılık 
göstermiş ve mağdur öğrencilerin daha fazla boyun eğici davranış gösterdikleri bulunmuştur.

Tartışma ve Sonuçlar: Elde edilen bulgulara göre, katılımcıların önemli bir kısmı (\%35.5) zorbalığa farklı rollerde (zorba, mağdur ya da zorba/mağdur) dahil olmaktadır. Bu süreçte erkek öğrenciler kız öğrencilere göre daha fazla rol almaktadır. Öğrenciler arasında en yaygın kullanılan ve maruz kalınan zorbalık türü olarak sözel ve dolaylı türler olduğu görülmektedir. Boyun eğme davranışı açısından, mağdur öğrenciler zorbalara göre bu davranışı daha çok sergilediklerini belirtirken, zorba öğrencilerin boyun eğme davranış puanlarının düşük olması beklenen bir sonuçtur. Çünkü zorba öğrencilerin genellikle diğer öğrencilere göre daha saldırgan, sosyal ve popüler niteliklere sahip oldukları bulunmuştur (Perren, 2000). Öte yandan, akran gruplarında boyun eğme davranışı bir zayıflık ya da güçsüzlük olarak algılanmaktadır. Önceki araştırmalarda da belirtildiği gibi boyun eğme davranışı mağdur öğrencilerin diğer öğrencilere göre daha çok kullandığı bir özellik olup; bu özellik akran gruplarındaki zorbalık olaylarında bir risk faktörü olarak ele alınmaktadır (Perren \& Alsaker, 2006; Schwartz et al., 1993; Schwartz et al., 2002). Bu çalışmanın bulguları birçok araştırma bulgusuyla tutarlılık gösterirken, okullarda zorbalığa karşı geliştirilecek önleyici ve gelişimsel programlarda ve müdahalelerde bu özelliklerin dikkate alınmasının önemli olduğu düşünülmektedir. 


\section{Zorbalık ve Boyun Ĕgme Davranışı*}

\section{${\text { Gökhan } \text { Atik }^{* *} \text { Onur ÖZMEN }}^{* * *}$ Gülşah KEMER ${ }^{* * * *}$}

ÖZ. Bu çalışmada, lise öğrencileri arasındaki zorbalı̆̆ın yaygınlığı ve türleri ve zorbalığa dahil olan öğrencilerin boyun eğme davranışları incelenmiştir. Çalışmaya Ankara'da üç lisede eğitimlerine devam eden 389 (\%59.6 erkek, \%40.4 kız) öğrenci katılmıştır. Revize Edilmiş Olweus Zorba/Mağdur Anketi (Olweus, 1996), Boyun Eğici Davranışlar Ölçeği (Gilbert \& Allan, 1994) ve kısa bir demografik bilgi formu kullanılmıştır. Araştırma sonuçlarına göre, zorbalık ve zorbalığın sözel ve dolaylı biçimleri öğrenciler arasında yaygın bir şekilde görülmektedir. Cinsiyet farklılı̆̆ı açısından, erkek öğrenciler kız öğrencilere göre zorbalığa daha çok dahil olmaktadır. Varyans analizi sonuçlarına göre, mağdur öğrenciler zorba gruptaki öğrencilere göre boyun eğici davranışları daha çok göstermektedir. Elde edilen bulgular alan yazın çerçevesinde tartışılmış ve okul psikolojik danışmanları ve eğitimciler için birtakım öneriler sunulmuştur.

Anahtar Sözcükler: Zorbalık, mağdur olma, çekingen davranış, lise öğrencileri.

\footnotetext{
* Bu çalışma Eylül 2009'da Avusturya'nın Viyana şehrinde yapılan Avrupa Eğitim Araştırmaları Konferansı'nda sözlü bildiri olarak sunulmuştur. Bu çalışmayla ilgili değerli görüşlerini bizle paylaşan Oya Yerin Güneri'ye çok teşekkür ederiz.

** Arş. Gör., Ankara Üniversitesi, Eğitim Bilimleri Fakültesi, Rehberlik ve Psikolojik Danışmanlık Anabilim Dalı, Ankara, Türkiye. E-posta: gatik@ankara.edu.tr

*** Orta Doğu Teknik Üniversitesi, Eğitim Fakültesi, Rehberlik ve Psikolojik Danışmanlık Anabilim Dal1, E-posta: onurozmen@msn.com

${ }^{* * * *}$ Kuzey Karolina Üniversitesi, Greensboro, Psikolojik Danışma ve Eğitimsel Gelişim Bölümü, Kuzey Karolina, Amerika Birleşik Devletleri. E-posta: g_kemer@uncg.edu
} 


\section{INTRODUCTION}

Bullying has become one of the most considerable concerns of students, parents, educators, and mental health professionals in school settings. This concern especially appeared to stem from the negative influences of bullying on students' well-being. In the literature, it was well-documented that bullying had deleterious influences on students' health and led to some emotional, behavioral, social, and academic problems, such as posttraumatic stress (Mynard, Joseph, \& Alexandera, 2000), depression (Çetinkaya, Nur, Ayvaz, Özdemir, \& Kavakc1, 2009; Sabuncuoğlu et al., 2006), hopelessness, loneliness, suicidal ideation (Fleming \& Jacobsen, 2009), problem behaviors, less social competence (Haynie et al., 2001), and lower academic achievement (Konishi, Hymel, Zumbo, \& Li, 2010). Moreover, higher prevalence of bullying in school settings seemed to be another concerning issue. For instance, in a comprehensive international study (Due, Holstein, \& Soc, 2008) almost one-third of 13-15-year-old school children $(N=218,104)$ were found to be bullied. Similarly, a high prevalence of bullying among elementary, middle (Atik, 2006; Kapc1, 2004; Özer \& Totan, 2009; Pişkin, 2010), and high school students (Alikasifoglu et al. 2004; Kepenekci \& Çınkır, 2006; Yöndem \& Totan, 2008) were also found in the Turkish studies. Yöndem and Totan (2008) found that $27 \%$ of 584 ninth- through eleventh-grade students reported being involved in bullying. Kepenekci and Çınkır (2006) also reported that each student participated in their study $(N=$ 692 ) were bullied at least once during the academic year. Almost $36 \%$ of those students were bullied physically, $33 \%$ verbally, $28.3 \%$ emotionally, and $15.6 \%$ sexually. Using a modified version of HBSC (Health Behavior in School-Aged Children) survey with 4,153 high school students, Alikasifoglu and colleagues (2004) found that $19 \%$ of students bullied other students and $30 \%$ were bullied. Although the pervasiveness of bullying and victimization among Turkish adolescents was addressed in these studies, it was apparent that the generalizability of the findings was limited to some regions or students who participated in these studies. Moreover, the differentiation among the findings of these studies was considered to be related to sample characteristics or use of different instruments for assessment of bullying and victimization (Atik, 2011). Therefore, more studies were required to describe bullying and victimization among Turkish adolescents more precisely.

Bullying occurred in a number of typologies, such as physical (e.g. hitting, kicking, punching, taking belongings), verbal (e.g. teasing, taunting), social exclusion, and indirect (e.g. spreading nasty rumors, telling others not to play with someone) (Smith \& Ananiadou, 2003). Sexual and racial harassment (Smith, Pepler, \& Rigby, 2004) and cyber-bullying (Kowalski \& 
Limber, 2007) were also regarded as different types of bullying. The most frequent types of bullying and victimization among Turkish adolescents were found to be verbal (Kepenekci \& Çınkır, 2006; Pişkin, 2010; Totan \& Yöndem, 2007) and physical forms (Kepenekci \& Çınkır, 2006; Pişkin, 2010). Bullying and victimization both were associated with gender and age. They were more prevalent among boys than girls (Bosworth, Espelage, \& Simon, 1999; Haynie et al., 2001; Nansel et al., 2001; Wang, Iannotti, \& Nansel, 2009). Bullying peaked during $6^{\text {th }}, 7^{\text {th }}$, and $8^{\text {th }}$ grades (Nansel et al., 2001) and decreased gradually during high school (Pellegrini \& Long, 2002). Also, while younger children tended to report more victimization (Kristensen \& Smith, 2003), older students were mostly involved in bullying and delinquency (Baldry \& Farrington, 2000).

The most widely used definition on bullying or victimization was provided by Olweus (1993, p. 9); "a student is being bullied or victimized when he or she is exposed, repeatedly and over time, to negative actions on the part of one or more other students". A subtype of aggressive behavior, bullying, was also described as a non-assertive behavior (Alberti \& Emmons, 1970). According to the authors' assertiveness theory, aggression and submissiveness were classified under the non-assertive behaviors. Aggressive persons were inclined to express themselves in hostile and coercive ways to meet their needs at expense of others, whereas submissive persons mostly behaved in non-hostile ways of hiding their actual feelings, allowing others to decide for them instead, ignoring their own needs (Alberti \& Emmons, 1970). Considering this theory, it was expected that bullies displayed less submissive behavior than victims. Literature supporting this theory described social behavior characteristics of students involved in bullying. Initially, Olweus (1994) described a type of victim, namely passive-submissive, characterized as anxious, insecure, and not likely to revenge when attacked. Perry, Willard, and Perry (1990) found children's perceptions regarding victimized peers' reactions to the attackers as less likely to retaliate, more likely to reward bully's behavior and suffer when they were bullied. Moreover, children displaying submissive and unassertive behaviors were found to be victimized more than the others (Schwartz, Dodge, \& Coie, 1993; Schwartz, Farver, Chang, \& Lee-Shin, 2002). In a similar vein, victimized children displayed more submissive, withdrawn behaviors and less assertive behaviors (Perren \& Alsaker, 2006; Tom, Schwartz, Chang, Farver, \& Xu, 2010) as well as less cooperative, sociable, and more isolated behaviors (Perren \& Alsaker, 2006). Although the association between victimization and submissiveness among children was well-documented in the literature, there was paucity of research with adolescents. In addition, Schwartz et al. (2002) claimed that the social 
process underlying bullying was limited to the knowledge gathered from the Western cultural settings. Therefore, current study was expected to contribute existing literature with a different cultural perspective.

Briefly, present study aimed at investigating the prevalence and types of bullying as well as examining the differences in submissive behaviors in terms of gender (females and males) and bully categories (bully, victim, bully/victim, and not involved) among Turkish adolescents. Research questions of the study were as follows: "What is the prevalence and nature of bullying among Turkish adolescents?", "Are there any gender and grade differences among students involved in bullying and not involved?", and "Do the mean scores of submissive behaviors significantly differ according to gender and bully categories among high school adolescents?"

\section{METHOD}

\section{Participants}

Participants of the present study were 389 students, 232 males (59.6\%) and 157 females (40.4\%), from three high schools in Ankara, Turkey. Convenient sampling strategy was used to recruit the students. Age of the participants ranged from 14 to 19 years $(M=15.92, S D=.92)$ with grade levels of $9^{\text {th }}(37.3 \%, n=145), 10^{\text {th }}(33.7 \%, n=131)$, and $11^{\text {th }}(29 \%, n=$ 113).

\section{Measures}

The Revised Olweus Bully/Victim Questionnaire (Olweus, 1996), Submissive Acts Scale (Gilbert \& Allan, 1994), and a brief demographic information form including questions about participants' gender, age and grade level were used to collect the data.

Bullying and victimization. The Revised Olweus Bully/Victim Questionnaire (ROBVQ) developed by Olweus (1996) was used to assess participants' bullying and victimization experiences. It was a 40 -item selfreport questionnaire. Combinations of the items for being victimized or bullying others yielded higher internal consistencies $(\alpha=.80$ to .90$)$. The items assessing being bullied or bullying others were correlated between .40 - .60 when analyzed with independent peer ratings (Olweus, 1994, 1996). The ROBVQ was translated into Turkish by Dölek (2002). Atik (2006) found the internal consistency coefficients of the questionnaire in a Turkish sample as .71 for victimization items and .75 for bullying items. Atik (2009) 
also examined the questionnaire's validity and reliability in a small sample. The total scores of victimization items were found to be positively correlated $(n=29 ; r=.47 ; p<.05)$ with the total scores of Kovacs' (1985) Children Depression Inventory whereas the total scores of bullying items were found to be positively correlated $(n=21 ; r=.43 ; p<.05)$ with the total scores of Crick and Grotpeter's (1995) Children's Social Behavior Scale. One-week stability of the two global questions ("How often have you been bullied at the school in the past couple of months?" and "How often have you taken part in bullying another student(s) at the school in the past couple of months?") was checked with percentage agreement (69.6\% for observed percentage agreement, $71.8 \%$ for expected percentage agreement).

In the present study, eight items pertaining to experience of being bullied, and eight items pertaining to bullying other students were used. The questionnaire begins with a required instruction as originally developed by Olweus (1996) including the definition and examples of bullying, and followed with two "global" questions. Following the instructions, seven specific questions about how often verbal, physical, indirect etc. forms of bullying were listed. Questions were responded on a five-point Likert-type scale ranging from "never" to "several times a week". Responses to the questions were mostly coded between the range of 0 and 4 or 1 and 5, according to their reported frequencies (Solberg \& Olweus, 2003).

In the current investigation, the participants were divided into two groups based on their responses to the two main (global) questions given above. Specifically, participants reporting "sometimes" or higher for the first question were defined as "victims", whereas those who reported "sometimes" or higher for the second question were classified as "bullies". Additionally, participants reported their involvement as at least sometimes or higher for both of the questions were identified as "bully-victims", while those who did not report higher frequencies than at least "sometimes" were defined as "not involved" group (non-victims/non-bullies). Groups were generated based on the cutoff point (at least sometimes) of the reported frequencies indicated by Solberg and Olweus (2003).

Submissive behavior. The Submissive Acts Scale (SAS) was used to assess students' submissive behavior. The SAS was originally developed for the study of Buss and Craik (1986). In their study, participants were asked to identify typical submissive behaviors. A 16-item scale of submissive behavior was defined by means of the responses (Gilbert \& Allan, 1994). In the scale, frequencies reported on each of the items (e.g. "I let others criticize me or put me down without defending myself") ranged from "never" to "always", based on a five-point Likert-type scaling. The higher 
scores indicate higher levels of submissive behavior. In the original study, alpha coefficient was found .89. Criterion validity assessments of the scale indicated that it was related to several constructs. For example, its correlation with Beck Depression Inventory was found as .73 (Gilbert, Allan, \& Trent, 1995). In adaptation of the scale into Turkish (Şahin \& Şahin, 1992), the internal consistency coefficient was found as relatively lower but still at the satisfactory level (.74). Correlation between Turkish version of the scale and Beck Depression Inventory was reported as .32. Moreover, Öngen (2006) examined the reliability coefficient of Turkish version of the scale on a high school sample as .74.

\section{Procedure}

Data collection set (ROBVQ, SAS, and a brief demographic information form including gender, age and grade level) were administered to the volunteer students in their classrooms by the first and second authors. The participants were informed regarding the purpose of the study and ensured about confidentiality. In addition, detailed instructions were given to the participants concerning their response to each instrument. Data collection lasted about 15-20 minutes in each of the sixteen classrooms. The data were collected on May, 2009.

\section{Analysis of Data}

To investigate prevalence and types of bullying and victimization, frequency analyses were performed. In order to test differences between involved and not involved groups in relation to gender and grade, two twoway contingency table analyses were carried out. Lastly, a two-way factorial ANOVA were run to examine the mean differences in submissive behavior scores of participants. All analyses were utilized with using the Statistical Package for Social Sciences (SPSS 15.0).

\section{RESULTS}

\section{Prevalence and Types of Bullying and Victimization}

Of the total 389 students, $8 \%(n=31)$ were identified as bully, $19.8 \%$ $(n=77)$ victim, 7.7\% $(n=30)$ bully/victim, and 64.5\% $(n=251)$ not involved. According to the descriptive analysis results, experiences of victims varied across the items related to being bullied. The most frequently mentioned item among victims was "being called names, teased in a hurtful 
way" in which $48.1 \%$ of them reported at least two or three times in a month. Similarly, the item "being bullied with mean names or comments about gesture or speaking" was reported by $36.4 \%$ of the victims as occurring at least two or three times in a month. The third frequent item reported by the victims was "being told lies, spread false rumors, disliked". This item was reported by $19.5 \%$ of the victims (again at least two or three times in a month).

The most frequently mentioned type of bullying behavior by bullies was "calling mean names, teasing in a hurtful way" (two or three times in a month by $25.8 \%$ of them). Similarly, $12.9 \%$ of the bullies reported "leaving out, excluding, ignoring" behavior at least two or three times in a month. Other reports of the bullies showed that they involved in most of the bullying behaviors at least once in a month, although their frequencies were relatively low (e.g. "taking away money or other things, or damaging"; "telling lies, spread of false rumors, disliking").

\section{Gender and Grade Level Differences (Involved vs. Not Involved)}

Participants of the present study categorized as bully, victim, or bully/victim were regrouped as "involved" to balance the group distributions for involved and not involved groups. Furthermore, two contingency table analyses were conducted to evaluate gender and grade differences among the groups. Cramer's $V$ effect sizes were taken as statistical reference for the analyses to avoid misleading interpretation of the data (Green \& Salkind, 2005). Statistically significant results were found for the involved vs. not involved groups in terms of gender (Pearson $\chi^{2}[1, n=389]=5.33, p=.02$, Cramer's $V=.12$ ). Male students $(67.4 \%)$ were higher in proportion in involved group than females $(32.6 \%)$. On the other hand, no significant differences were found among the groups in terms of grade level (Pearson $\chi^{2}[2, n=389]=2.74, p=.25$, Cramer's $V=.08$ ).

\section{Results of Factorial ANOVA}

Prior to the analyses, the assumptions of two-way ANOVA, namely normality, homogeneity of variance, and interval measure level were checked. Specifically, skewness and kurtosis values, Q-Q plots, histograms, Kolmogorov-Smirnov, and Shapiro-Wilk's tests were checked for the normality assumption. No value violating the normality assumption was observed. Similarly, homogeneity of variance was checked via Levene's test for homogeneity of error variance. It was found to be insignificant $[F(7,381)$ $=.88, p>.05)]$. Therefore, homogeneity of variance assumption was met. 
Lastly, since the scores of the dependent variable in the study were continuous, the interval measure level assumption was met as well.

A 2 (gender: female vs. male) x 4 (bully category: bully, victim, bully/victim, and not involved) factorial ANOVA was performed to examine mean differences in submissive behavior scores. Means and standard deviations for mean scores of submissive behavior in terms of gender and bully categories were presented in Table 1 .

Table 1. Descriptive statistics for submissive behavior scores in terms of gender and bully categories

\begin{tabular}{|c|c|c|c|c|c|c|c|c|c|c|c|c|}
\hline \multirow[b]{3}{*}{ Gender } & \multicolumn{12}{|c|}{ Submissive Behavior } \\
\hline & \multicolumn{3}{|c|}{ Not Involved } & \multicolumn{3}{|c|}{ Victim } & \multicolumn{3}{|c|}{ Bully } & \multicolumn{3}{|c|}{ Bully/Victim } \\
\hline & $n$ & $M$ & $S D$ & $n$ & $M$ & $S D$ & $n$ & $M$ & $S D$ & $n$ & $M$ & $S D$ \\
\hline Female & 112 & 36.7 & 9.4 & 22 & 38.4 & 10.1 & 15 & 33.7 & 6.7 & 8 & 44.5 & 11.9 \\
\hline Male & 139 & 40.8 & 9.1 & 55 & 41.0 & 10.0 & 16 & 35.6 & 11.2 & 22 & 38.1 & 10.0 \\
\hline Total & 251 & 39.0 & 9.4 & 77 & 40.3 & 10.0 & 31 & 34.7 & 9.2 & 30 & 39.8 & 10.7 \\
\hline
\end{tabular}

As seen in Table 1, mean submissive behavior scores of females were higher than males for "bully/victim" category $(M=44.5, S D=11.9)$, while the mean scores of submissive behavior for males were higher than females in the "not involved" $(M=40.8, S D=9.1)$, "victim" $(M=41.0, S D=10.0)$, and "bully" $(M=35.6, S D=11.2)$ categories.

Results of the $2 \times 4$ factorial ANOVA indicated that main effect of the bully categories was significant $[F(3,381)=2.68, p<.05]$, whereas the main effect of gender was found to be insignificant $[F(1,381)=.14, p>$ .05]. Similarly, interaction effect of gender and bully categories was found as statistically insignificant $[F(3,381)=2.22, p>.05]$. Table 2 showed the results of two-way factorial ANOVA in detail.

Table 2. Results of ANOVA for the effects of gender and bully categories on submissive behavior

\begin{tabular}{lcccl}
\hline Source & $S S$ & $d f$ & $M S$ & $F$ \\
\hline Gender & 12.48 & 1 & 12.48 & .14 \\
Bully Categories & 726.8 & 3 & 242.27 & $2.68^{*}$ \\
Gender*Bully Categories & 600.25 & 3 & 200.08 & 2.22 \\
\hline
\end{tabular}

$*$ Note. $p<.05$ 
The differences in mean scores of submissive behavior were examined with post-hoc analysis to find out which one of the bully categories caused statistically significant difference in submissive behavior scores. Tukey's test was utilized for further analysis of the data. Results showed that mean difference between victims and bullies $(M D=5.59, S E=2.02)$ to be statistically significant. This difference indicated that victims reported more submissive behaviors than those of bullies.

\section{DISCUSSION}

The premise for performing this study was to extend the existing literature by providing evidence for prevalence and types of bullying among Turkish high school students and submissive behavior characteristics of students involved in bullying. Initially, the findings regarding prevalence of bullying and victimization indicated that at least one third of the students $(35.5 \%)$ were involved in bullying as bully, victim, or bully/victim. Among these involved students, victims had a higher proportion (19.8\%). On the other hand, the proportion of bullies (8\%) and bully/victims $(7.7 \%)$ were relatively low. These ratios appeared to be very close to the findings of some earlier studies obtained from elementary, middle (Atik, 2006; Atik \& Kemer, 2008; Dölek, 2002; Özer \& Totan, 2009) and high school samples (Yöndem \& Totan, 2008) in Turkey. This finding should be examined in light of the findings by Kert, Codding, Tryon, and Shiyko (2010), which indicated that self-report measures including word of bully in the items and definitions underestimated bullying behaviors. The prevalence of bullying and victimization could be higher than was reported, which is an important consideration while dealing with bullying.

The most frequent types of bullying behaviors experienced by the victims and used by the bullies were verbal and indirect forms which were consistent with the previous studies in Turkey (Atik, 2006; Kartal, 2008; Totan \& Yöndem, 2007). When gender and grade level differences were investigated in relation to bullying, only meaningful gender differences were found among the groups (involved vs. not involved). Male students had a larger percentage in involving bullying confirming the previous findings that bullying and victimization both were more prevalent among males than females (Nansel et al., 2001; Wang et al., 2009).

The results of the current study regarding submissive behavior were also consistent with the previous research findings. It was found that victims demonstrated more submissive behaviors than bullies. Past researchers concluded that victims were more submissive than the other students, and also, being submissive was an individual risk factor for victimization in peer 
groups that perceived as a weakness and powerlessness (Perren \& Alsaker, 2006; Schwartz et al., 1993; Schwartz et al., 2002). The lower submissive scores for bullies was an expected result, because bullies were more aggressive, social, and popular than other students (Perren, 2000).

Our findings could provide some implications for school counselors. Toblin, Schwartz, Gorman, and Abou-ezzeddine (2005) suggested that various intervention strategies should apply to students who involved in bullying in a different way (as bully, victim, or bully/victim) in schools. For example, teaching coping skills and anger management to aggressive victims and disproving social information processing biases of bullies might work much better. However, while counseling with submissive victims, designing an intervention strategy focused on assertiveness training and self-esteem building could help them.

Prevalence of bullying and victimization in the present sample were an indication of its seriousness. Therefore, besides individual intervention with victims or bullies, holistic school prevention strategies would be better. The other members of school community, such as teachers, parents, school personnel, and students at risk or not, should be involved in the intervention program. Peer counseling and mediation programs, peer support mechanisms, social skills training, conflict resolution, class and school rules against bullying could be applied to increase the effectiveness of intervention program while dealing with bullying at the school and class level (Smith, Pepler, \& Rigby, 2004).

Educators could also benefit from the findings of this study. Bullying is a threat to school climate and could easily harm the feeling of belonging to a community. As discussed in Osterman's article (2000), being a part of a group or community provided an emotional support for productive learning. Also, feeling of belonging or relatedness including secure connection with others, feelings of worthy, and respect was a crucial psychological need in human development. Therefore, educators should focus on not only students' academic achievement, but also students' psychological needs. They should take the role for creating positive, safe, and supportive school climate. Concerning our results, students demonstrating submissive behaviors will need much support from their close environment, especially from their teachers. In this respect, designing class activities enhancing group cohesion and self-esteem could be a tool in creation of safer school climate.

There were certain limitations of the present study. Firstly, generalizability of the results was limited to this sample and these schools. Also, findings of the study were limited to data collected from self-reported questionnaires. However, as stated in the studies (Branson \& Cornell, 2009; Chan, 2009), in identifying bullies, victims, and bully/victims various 
assessment procedures such as peer and teacher nomination and behavioral observation could be used. Moreover, the present study focused on only submissive behaviors of students involved in bullying. However, the focus could be widened and the other constructs of social behavior (e.g. assertiveness, withdrawal, shyness, cooperation, competition) could be included in further research designs.

\section{REFERENCES}

Alberti, R. E., \& Emmons, M. L. (1970). Your perfect right: A guide to assertive behavior. San Luis Obispo, California: Impact.

Alikasifoglu, M., Erginoz, E., Ercan, O., Uysal, O. Kaymak, D. A., \& Ilter, O. (2004). Violent behaviour among Turkish high school students and correlates of physical fighting. European Journal of Public Health, 14(2), 173-177.

Atik, G. (2009). Zorbalığı yordayıcı bir değişken olarak umut [Hope as a predictor of bullying]. Ankara Üniversitesi Eğitim Bilimleri Fakültesi Dergisi, 42(1), 53-68.

Atik, G. (2006). The role of locus of control, self-esteem, parenting style, loneliness, and academic achievement in predicting bullying among middle school students school students (Unpublished master's thesis). Middle East Technical University, Ankara.

Atik, G. (2011). Assessment of school bullying in Turkey: A critical review of self-report instruments. Procedia Social and Behavioral Sciences, $15,3232-3238$.

Atik, G., \& Kemer, G. (2008). İlköğretim ikinci kademe öğrencileri arasındaki zorbalığı yordamada problem çözme becerisi, sürekli öfkeöfke ifade tarzları ve fiziksel özyeterliğin rolü [The role of problem solving skills, state-trait anger expression styles, and physical selfefficacy in predicting bullying among middle school students]. 9 Eylül Üniversitesi Buca Eğitim Fakültesi Dergisi, 23, 198-206.

Baldry, A. C., \& Farrington, D. P. (2000). Bullies and delinquents: Personal characteristics and parental styles. Journal of Community \& Applied Social Psychology, 10, 17-31.

Bosworth, K., Espelage, D. L., \& Simon, T. R. (1999). Factors associated with bullying behavior in middle school students. Journal of Early Adolescence, 19(3), 341-362.

Branson, C. E., \& Cornell, D. G. (2009). A comparison of self and peer reports in the assessment of middle school bullying. Journal of Applied School Psychology, 25, 5-27. 
Buss, D. M., \& Craik, K. H. (1986). Acts, dispositions and clinical assessment: The psychopathology of everyday conduct. Clinical Psychology Review, 6, 387-406.

Chan, J. H. F. (2009). Where is the imbalance? Journal of School Violence, $8(2), 177-190$.

Crick, N. R., \& Grotpeter, J. K. (1995). Relational aggression, gender, and social psychological adjustment. Child Development, 66, 710-722.

Çetinkaya, S., Nur, N., Ayvaz, A., Özdemir, D., \& Kavakcı, Ö. (2009). Sosyo-ekonomik durumu farklı üç ilköğretim okulu öğrencilerinde akran zorbalığının depresyon ve benlik saygısı düzeyiyle ilişkisi [The relationship between school bullying and depression and self-esteem levels among the students of three primary schools with different socioeconomic levels]. Anadolu Psikiyatri Dergisi, 10, 151-158.

Dölek, N. (2002). Illk ve orta ögretim okullarındaki öğrenciler arasında zorbaca davranışları incelenmesi ve "zorbalı̆̆ önleme tutumu geliştirilmesi programı"nın etkisinin araştırılması [An investigation of bullying behaviors among elementary and high school students and the effect of program "developing bullying prevention attitudes"] (Unpublished doctoral dissertation). Marmara University, Istanbul.

Due, P., Holstein, B. E., \& Soc, M. S. (2008). Bullying victimization among 13 to 15-year-old school children: Results from two comparative studies in 66 countries and regions. International Journal of Adolescent Medicine and Health, 20(2), 209-221.

Fleming, L. C., \& Jacobsen, K. H. (2009). Bullying among middle-school students in low and middle income countries. Health Promotion International, 25(1), 73-84.

Gilbert, P., \& Allan, S. (1994). Assertiveness, submissive behavior and social comparison. British Journal of Clinical Psychology, 33, 295-306.

Gilbert, P., Allan, S., \& Trent, D. (1995). Involuntary sub-ordination or dependency as key dimensions of depressive vulnerability. Journal of Clinical Psychology, 51, 740-752.

Green, S., \& Salkind, N. (2005). Using SPSS for Windows and Macintosh ( $4^{\text {th }}$ ed.). Upper Saddle River, NJ: Pearson Prentice Hall.

Haynie, D. L., Nansel, T., Eitel, P., Crump, A. D., Saylor, K., Yu, K., \& Simons-Morton, B. (2001). Bullies, victims, and bully/victims: Distinct groups of at-risk youth. Journal of Early Adolescence, 21(1), 29-49.

Kapcı，E. G. (2004). İlköğretim öğrencilerinin zorbalığa maruz kalma türünün ve sıklığının depresyon, kaygı ve benlik saygısıyla ilişkisi [Bullying type and severity among elementary school students and its relationship with depression, anxiety and self esteem]. Ankara Üniversitesi Ĕ̈itim Bilimleri Fakültesi Dergisi, 37, 1-13. 
Kartal, H. (2008). Bullying prevalence among elementary students. H.U. Journal of Education, 35, 207-217.

Kepenekci, Y. K., \& Çınkır, Ş. (2006). Bullying among Turkish high school students. Child Abuse \& Neglect, 30(2), 193-204.

Kert, A. S., Codding, R. S., Tryon, E. S., \& Shiyko, M. (2010). Impact of the word bully on the reported rate of bullying behavior. Psychology in the Schools, 47(2), 193-204.

Kristensen, S. M., \& Smith, P. K. (2003). The use of coping strategies by Danish children classed as bullies, victims, bully/victims, and not involved, in response to different (hypothetical) types of bullying. Scandinavian Journal of Psychology, 44(5), 479-488.

Konishi, C., Hymel, S., Zumbo, B. D., \& Li, Z. (2010). Do school bullying and student-teacher relationships matter for academic achievement? A multilevel analysis. Canadian Journal of School Psychology, 25(1), 1939.

Kovacs, M. (1985). The Children's Depression Inventory. Psychopharmacology Bulletin, 21, 995-998.

Kowalski, R. M., \& Limber, S. P. (2007). Electronic bullying among middle school students. Journal of Adolescent Health, 41(6), 22-30.

Mynard, H., Joseph, S., \& Alexandera, J. (2000). Peer-victimisation and posttraumatic stress in adolescents. Personality and Individual Differences, 29, 815-821.

Nansel, T. R., Overpeck, M., Pilla, R. S., Ruan, W. J., Simons-Morton, B., \& Scheidt, P. (2001). Bullying behaviors among US youth: Prevalence and association with psychosocial adjustment. JAMA, 285(16), 20942100.

Olweus, D. (1993). Bullying at school: What we know and what we can do. Oxford, UK; Cambridge, USA: Blackwell.

Olweus, D. (1994). Bullying at school: Basic facts and effects of a school based intervention program. The Journal of Child Psychology and Psychiatry, 35(7), 1171-1190.

Olweus, D. (1996). The Revised Olweus Bully/Victim Questionnaire for students. Bergen, Norway: University of Bergen.

Osterman, K. F. (2000). Students' need for belonging in the school community. Review of Educational Research, 70(3), 323-367.

Öngen, D. E. (2006). The relationship between self-criticism, submissive behavior and depression among Turkish adolescents. Personality and Individual Differences, 41, 793-800.

Özer, A., \& Totan, T. (2009, October). İlköğretim öğrencilerinin cinsiyetlerine, başarl seviyelerine ve öz yeterliklerine göre zorballk statülerinin incelenmesi [An investigation of bullying status of 
elementary school students regarding gender, academic achievement, and self-efficacy]. Paper presented at the X. National Psychological Counseling and Guidance Congress, Adana, Turkey.

Pellegrini, A. D., \& Long, J. D. (2002). A longitudinal study of bullying, dominance, and victimization during the transition from primary school through secondary school. The Journal of Developmental Psychology, 20, 259-280.

Perren, S. (2000). Kindergarten children involved in bullying: Social behavior, peer relationships, and social status (Unpublished doctoral dissertation). The University of Bern, Bern.

Perren, S., \& Alsaker, F. D. (2006). Social behavior and peer relationships of victims, bully-victims, and bullies in kindergarten. The Journal of Child Psychology and Psychiatry, 47(1), 45-57.

Perry, D. G., Williard, J. C., \& Perry, L. C. (1990). Peers' perceptions of the consequences that victimized children provide aggressors. Child Development, 61, 1310-1325.

Pişkin, M. (2010). Examination of peer bullying among primary and middle school children in Ankara. Education and Science, 35(156), 175-189.

Sabuncuoğlu, O., Ekinci, Ö., Bahadır, T., Akyuva, Y., Altınöz, E., \& Berkem, M. (2006). Ergen öğrenciler arasında akran örselemesi ve depresyon belirtileriyle ilişkisi [Bullying and its relationship to symptoms of depression in adolescent students]. Klinik Psikiyatri, 9, $27-35$.

Schwartz, D., Dodge, K. A., \& Coie, J. D. (1993). The emergence of chronic peer victimization in boys' play groups. Child Development, 64(6), 1755-1772.

Schwartz, D., Farver, J. M., Chang, L., \& Lee-Shin, Y. (2002). Victimization in South Korean children's peer groups. Journal of Abnormal Child Psychology, 30(2), 113-125.

Smith, P. K., \& Ananiadou, K. (2003). The nature of school bullying and the effectiveness of school-based interventions. Journal of Applied Psychoanalytic Studies, 5(2), 189-208.

Smith, P. K., Pepler, D. J., \& Rigby, K. (2004). Bullying in schools: How successful can interventions be? New York: Cambridge University Press.

Solberg, M. E., \& Olweus, D. (2003). Prevalence estimation of school bullying with the Olweus Bully/Victim Questionnaire. Aggressive Behavior, 29(3), 239-268.

Şahin, N. H., \& Şahin, N. (1992, June). Adolescent guilt, shame, and depression in relation to sociotropy and autonomy. Paper presented at the World Congress of Cognitive Therapy, Toronto, Canada. 
Toblin, R. L., Schwartz, D., Gorman, A. H., \& Abou-ezzeddine, T. (2005). Social-cognitive and behavioral attributes of aggressive victims of bullying. Applied Developmental Psychology, 26, 329-346.

Totan, T., \& Yöndem, Z. D. (2007). Ergenlerde zorbalığın anne, baba ve akran ilişkileri açısından incelenmesi [The investigation of bullying in adolescence related to parent and peer relations]. Ege Eğitim Dergisi, $8(2), 53-68$.

Tom, S. R., Schwartz, D., Chang, L., Farver, J. A. M., \& Xu, Y. (2010). Correlates of victimization in Hong Kong children's peer groups. Journal of Applied Development Psychology, 31, 27-37.

Wang, J., Iannotti, R. J., \& Nansel, T. R. (2009). School bullying among adolescents in the United States: Physical, verbal, relational, and cyber. Journal of Adolescent Health, 45, 368-375.

Yöndem, Z. D., \& Totan, T. (2008). Ergenlerde zorbalık ve stresle başetme [Bullying and coping with stress in adolescents]. Çukurova Üniversitesi Eğitim Fakültesi Dergisi, 3(35), 28-37. 